\title{
Increased expression of Myc-interacting zinc finger protein 1 in APP/PS1 mice
}

\author{
LU LIU $^{1}$, YU-JIE LAI ${ }^{2}$, LI-GE ZHAO ${ }^{1}$ and GUO-JUN CHEN ${ }^{1}$ \\ ${ }^{1}$ Department of Neurology, The First Affiliated Hospital of Chongqing Medical University, \\ Chongqing Key Laboratory of Neurology, Chongqing 400016; ${ }^{2}$ Department of Neurology, \\ The Third Affiliated Hospital of Chongqing Medical University, Chongqing 401120, P.R. China
}

Received February 9, 2017; Accepted June 2, 2017

DOI: $10.3892 / \mathrm{etm} .2017 .5289$

\begin{abstract}
Myc-interacting zinc-finger protein 1 (Miz1) is a member of the poxvirus and zinc-finger domain/zinc finger transcription factor family. Its transcription activation and repression functions in the nucleus are well elucidated; however its cytoplasmic inflammation function is poorly understood and may be associated with the pathogenesis of Alzheimer's disease (AD). The aim of the present study was to investigate the association between AD and Miz1 expression. In the present study, the expression and distribution of Miz1 in wild-type (WT) and amyloid precursor protein/presenelin-1 (AD) mice was studied using reverse transcription-quantitative polymerase chain reaction, western blot analysis, and immunohistochemical and immunofluorescence staining. The results indicated that Miz1 was significantly upregulated in the cortex of AD mice $(\mathrm{P}<0.05)$. Double immunofluorescence labeling revealed that Mizl protein was predominantly expressed in neurons and astrocytes, as evidenced by co-localization with the dendritic markers microtubule associated protein 2 and glial fibrillary acidic protein, respectively. The results of the present study suggest that the expression of Miz1 in the brain tissue of AD mice may serve an important role in AD pathogenesis.
\end{abstract}

\section{Introduction}

Alzheimer's disease (AD) is the leading cause of dementia worldwide and is characterized by the accumulation of amyloid- $\beta$ plaques $(A \beta)$, neurofibrillary tangles, synaptic and neuronal losses, and cognitive decline (1). Accumulation of $A \beta$ and activation of neuro-inflammatory cytokines are directly

Correspondence to: Dr Guo-Jun Chen, Department of Neurology, The First Affiliated Hospital of Chongqing Medical University, Chongqing Key Laboratory of Neurology, 1 Youyi Road, Chongqing 400016, P.R. China

E-mail: woodchen2015@163.com

Key words: Alzheimer's disease, Myc-interacting zinc-finger protein 1, APP/PS1 mice, cognition associated with memory disturbances in the early stages of disease $(2,3)$. Although the molecular mechanisms underlying these changes remain to be elucidated, alterations in transcription factors have been implicated in neuronal dysfunction, excitotoxic cascades and the production of toxic proteins in $\mathrm{AD}(4-6)$.

A previous RNA-sequencing analysis in acutely isolated neurons revealed that transcription factor Myc-interacting zinc-finger protein 1 (Miz1) was differentially expressed in amyloid precursor protein/presenelin-1 (APP/PS1) mice compared with age-matched control littermates (7). Miz1, also called protein inhibitor of activated signal transducer and activation of transcription 2 (PIAS2), was initially identified as an interacting protein of transcription factor c-Myc (8-10). It contains 13 zinc fingers at the $\mathrm{C}$-terminus and a poxvirus and zinc-finger domain at the $\mathrm{N}$-terminus, which is required for transcriptional activation $(11,12)$. Miz1 serves a critical role in proliferation, differentiation, cell-cycle progression, apoptosis, and autophagy via transcriptional activation and repression of its target genes (13-19). However, few studies have investigated the association between Miz1 and AD.

In the present study, the expression patterns of Miz1 were examined in APP/PS1 mice and an increase in Miz1 expression was observed in the cortex but not in the hippocampus. Mizl was also expressed in the cell bodies and dendrites of neurons and astrocytes, which indicated that alterations in Miz1 may be associated with the pathophysiology of AD.

\section{Materials and methods}

Ethics statement. All animal experiments in the present study were reviewed and approved by the Ethics Committee of Chongqing Medical University (Chongqing, China; approval no. 0002648).

Mice. A total of 30 male APP/PS1 transgenic mice with a C57BL/6J genetic background $(n=15)$ and their wild-type littermates $(\mathrm{n}=15)$ were purchased from the Model Animal Research Center of Nanjing University (Nanjing, China). All mice (20-25 g; 7 months of age) were housed in standard cages $\left(48 \times 26 \mathrm{~cm}^{2}\right)$ with 5 animals per cage. Mice were kept in a room at a controlled temperature $\left(22 \pm 1^{\circ} \mathrm{C}\right)$ under a 12 -h light/dark cycle and fed a pellet rodent diet and water ad libitum. All 
mice protocols were approved by the Chongqing Medical University Animal Welfare Committee. Specific primers for the APP and PS1 genes were designed by Sangon Biotech Co., Ltd. (Shanghai, China) as follows: APP forward, 5'-GAC TGACCACTCGACCAGGTTCTG-3' and reverse, 5'-CTT GTAAGTTGGATTCTCATATCCG-3'; PS1 forward, 5'-AAT AGAGAACGGCAGGAGCA-3' and reverse, 5'-GTGGAT AACCCCTCCCCCAGCCTAGACC-3', which have been accepted for the identification of APP/PS1 mice $(19,20)$. Mice were kept until they were 7 months old, as at this age mice display both pathological and behavioral abnormalities, including $A \beta$ deposition and cognitive impairment $(21,22)$. For immunofluorescence analysis, brain tissues were fixed in $4 \%$ paraformaldehyde, $20 \%$ sucrose in PBS, and $30 \%$ sucrose in PBS, and subsequently sectioned into $10-\mathrm{mm}$-thick frozen slices. For western blot analysis, the neocortex and hippocampus were dissected quickly using RNase-free instruments and stored in liquid nitrogen for further use.

Reagents. Antibodies against PIAS2 were from Abcam (Cambridge, MA, USA; 1:1,000) and antibodies against Miz1 were purchased from BIOSS (Beijing, China; bs-11234R; 1:40). Antibodies against glial fibrillary acidic protein (GFAP) were purchased from Boster Biological Technology (BM4393, Pleasanton, CA, USA; 1:100) and antibodies against microtubule-associated protein 2 (MAP2) were purchased from Boster Biological Technology (Pleasanton, CA, USA; BM1243; 1:100). Alexa Fluor 555-labeled donkey anti-mouse IgG $(\mathrm{H}+\mathrm{L})$ (1:200; A0460) and Alexa Fluor 488-labeled goat anti-rabbit IgG (H+L) (1:200; A0423) were from Beyotime Institute of Biotechnology (Haimen, China), and horseradish peroxidase (HRP)-conjugated anti-rabbit secondary antibody (151341AP; 1:5,000) and HRP-conjugated anti-mouse secondary antibody (HRP66008; 1:5,000) were from ProteinTech Group, Inc. (Chicago, IL, USA). Secondary goat anti-rabbit antibody was purchased from OriGene Technologies, Inc. (Rockville, MD, USA; TA130021; 1:100).

Immunohistochemistry. Paraffin-embedded sections of brain tissue were deparaffinized in xylene and rehydrated in a graded series of ethanol prior to staining. After dewaxing and incubation in $3 \% \mathrm{H}_{2} \mathrm{O}_{2}$ for $30 \mathrm{~min}$ at $37^{\circ} \mathrm{C}$, sections were washed with PBS and boiled in $10 \mathrm{mmol} / 1$ sodium citrate buffer ( $\mathrm{pH}$ 6.0; Boster Biological Technology) for $15 \mathrm{~min}$ at $92-98^{\circ} \mathrm{C}$ for antigen retrieval. The sections were then blocked in goat serum (Boster Biological Technology; $10 \%$ ) for $60 \mathrm{~min}$ at $37^{\circ} \mathrm{C}$. The sections were incubated with a 1:40 dilution of primary anti-Miz1 antibody overnight at $4^{\circ} \mathrm{C}$. Sections were then washed three times for $15 \mathrm{~min}$ in PBS, incubated with secondary goat anti-rabbit antibody (TA130021; 1:100; OriGene Technologies, Inc.) for $30 \mathrm{~min}$ at $37^{\circ} \mathrm{C}$, washed again, incubated with HRP-conjugated streptavidin (OriGene Technologies, Inc.) for $30 \mathrm{~min}$ at $37^{\circ} \mathrm{C}$ and washed again. Sections were then incubated with 3,3'-diaminobenzidine (DAB; OriGene Technologies, Inc.) for $2 \mathrm{~min}$ at room temperature, a process which was then terminated using water. Hematoxylin was used to counterstain the nuclei at room temperature for $1 \mathrm{~min}$. Subsequently, samples were dehydrated in lithium carbonate for $1 \mathrm{~min}$, incubated with dimethylbenzene for $5 \mathrm{~min}$ at room temperature, mounted, and dried overnight. Finally, images were captured using light microscopy (Nikon Corporation, Tokyo, Japan).

Reverse transcription-quantitative polymerase chain reaction $(R T-q P C R)$. RTq-PCR was performed as described previously (23). Total RNA was isolated from brain tissues using TRIzol reagent (Thermo Fisher Scientific, Inc., Waltham, MA, USA) and reverse transcribed using HiScript II Reverse Transcriptase (R201-01/02; Vazyme Biotech Co., Ltd., Nanjing, China) and random primers in a $\mathrm{PCR}$ reaction procedure $\left(25^{\circ} \mathrm{C}\right.$ for $5 \mathrm{~min}, 42^{\circ} \mathrm{C}$ for $15 \mathrm{~min}$ and $85^{\circ} \mathrm{C}$ for $5 \mathrm{~min}$ ). qPCR was performed on the Mastercycler ep realplex qPCR System (Eppendorf, Hamburg, Germany) with the SYBR-Green qPCR Master Mix (Vazyme Biotech Co., Ltd., Jiangsu, China) with specific primers for Mizl and $\beta$-actin as an internal control. An Eppendorf Real Time PCR system was used with the following parameters: One cycle at $95^{\circ} \mathrm{C}$ for $30 \mathrm{sec}$, followed by 40 cycles at $95^{\circ} \mathrm{C} 5 \mathrm{sec}, 60^{\circ} \mathrm{C}$ for $34 \mathrm{sec}$, and one cycle at $95^{\circ} \mathrm{C}$ for $15 \mathrm{sec}, 60^{\circ} \mathrm{C}$ for $1 \mathrm{~min}$ and $95^{\circ} \mathrm{C}$ for $15 \mathrm{sec}$. The median value of the replicates for each sample was calculated according to the $2^{-\Delta \Delta \mathrm{Cq}}$ method (24). Data presented were the mean from 3 independent experiments. Primers used were as follows: Mizl forward, 5'-AGGCACACTGTCTGAGAA GAGA-3' and reverse, 5'-TGGTTCAGCTGCTCCAAGA-3'; and $\beta$-actin forward, 5'-ACGGTCAGGTCATCACTATCG-3' and reverse, 5'-GGCATAGAGGTCTTTACGGATG-3'.

Western blot analysis. Proteins were extracted from mice cortex and hippocampus using radioimmunoprecipitation assay buffer (P0013E; Beyotime Institute of Biotechnology). Protein concentrations were measured using a bicinchoninic acid protein assay kit (Beyotime Institute of Biotechnology). Equal amounts of protein $(50 \mu \mathrm{g})$ were separated by $8 \%$ SDS-PAGE and electroblotted onto polyvinylidene difluoride membranes (EMD Millipore, Billerica, MA, USA) using an electrophoretic transfer system. The membranes were blocked with $5 \%$ non-fat dry milk in Tris buffered saline and Tween-20 (TBST) for $1 \mathrm{~h}$ at room temperature, and incubated with primary antibodies against Miz1 and GAPDH overnight at $4^{\circ} \mathrm{C}$. The blots were subsequently incubated with HRP-conjugated anti-rabbit and anti-mouse secondary antibodies (both 1:5,000; ProteinTech Group, Inc.) for $1 \mathrm{~h}$ at room temperature and washed in TBST 3 times for 5 min each time. The bands were visualized using an enhanced chemiluminescence reagent (Thermo Fisher Scientific, Inc.) and a Fusion FX5 image analysis system (Vilber Lourmat, Marne-la-Vallée, France). Quantity One software 4.6.2 (Bio-Rad Laboratories, Inc., Hercules, CA, USA) was used to measure the resultant optical density values.

Immunofluorescence. The sections of brain tissue were incubated at room temperature in acetone for $30 \mathrm{~min}$, washed with PBS, permeabilized with $0.4 \%$ Triton-X for $10 \mathrm{~min}$, and washed again with PBS. Following antigen retrieval with $10 \mathrm{mM} / 1$ sodium citrate buffer by heating at $9-98^{\circ} \mathrm{C}$ for $20 \mathrm{~min}$, sections were washed with PBS again and blocked against non-specific antigen by incubation at room temperature with goat serum working liquid (Boster Biological Technology; 10\%) for $1 \mathrm{~h}$, and incubated in primary anti-Miz1/MAP2/GFAP antibodies overnight at $4^{\circ} \mathrm{C}$. Proteins were subsequently detected by 


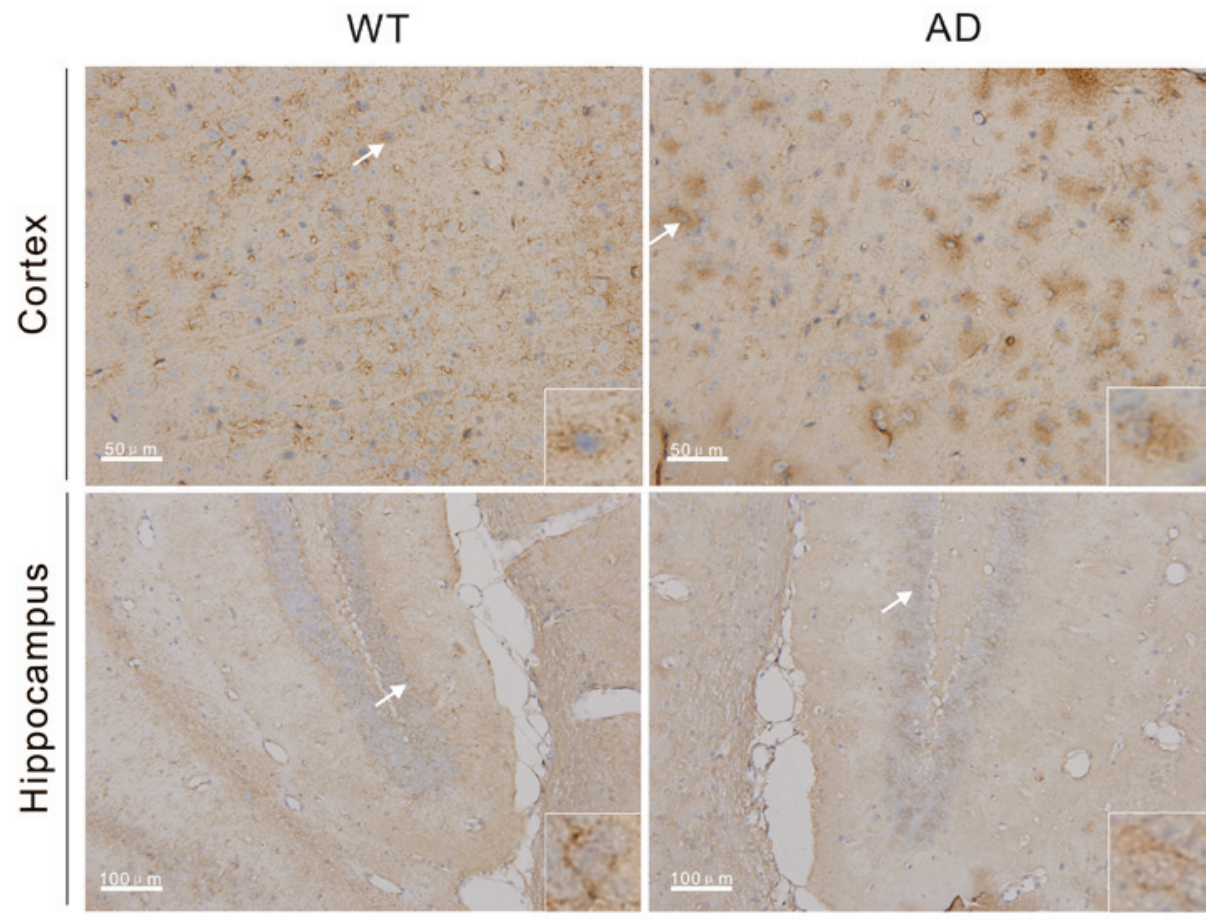

Figure 1. Miz1 immunoreactivity in the cortex and hippocampus of WT and AD mice. Sections of cortex and hippocampus from WT mice and a amyloid precursor protein/presenelin-1 mouse model of AD evaluated using immunohistochemistry, which revealed Mizl in the cytoplasm of neurons in the cortex and in the hippocampus. The expression of Miz1 was markedly higher in the cortex of AD compared with WT mice. Scale bar=50 $\mu \mathrm{m}$. Miz1, Myc-interacting zinc-finger protein 1; WT, wild-type; AD, Alzheimer's disease.

incubation with Alexa Fluor 488 goat anti-rabbit $\operatorname{IgG}$ and Alexa Fluor 555 donkey anti-mouse IgG secondary antibodies $(1: 200)$ in the dark for $1 \mathrm{~h}$ at $37^{\circ} \mathrm{C}$. Sections were subsequently washed and counterstained with 4,6-diamidino-2-phenylindole (DAPI) for $15 \mathrm{~min}$ at room temperature and washed with PBS. Finally, the sections were visualized by confocal laser scanning microscopy (Nikon Corporation).

Statistical analysis. All data are presented as the mean \pm standard error of the mean. Results were analyzed using Student's t-test. All statistical calculations were performed using SPSS 20.0 software (IBM Corp., Armonk, NY, USA). P $<0.05$ was considered to indicate a statistically significant difference.

\section{Results}

Mizl expression in the brain detected by immunohistochemistry. It is known that Miz1 serves a regulatory role in inflammation, which may provide a critical transcriptional checkpoint to prevent excessive inflammatory responses and tissue damage in the host. To determine the role of Miz1 in Alzheimer's disease, the expression of Miz1 was analyzed in the brains of wild-type (WT) mice and APP/PS1 (AD) mice at the age of 7 months using immunohistochemistry, and brown staining indicated that cells were positive for Mizl expression. Miz1 expression was detected in brain tissues from the WT and AD mice (Fig. 1). Compared with WT mice, expression of Miz1 was markedly increased in the cortex of $\mathrm{AD}$ mice at 7 months of age. However, no marked differences were observed in Miz1 expression in the hippocampus of WT and AD mice. In cortex and hippocampus tissues from both groups, Mizl was primarily located in the cytoplasm (Fig. 1).
Elevated Mizl expression in the cortex of $A D$ mice. Western blot analysis was conducted to determine the expression of Miz1 protein in the brains of WT $(n=6)$ and AD $(n=6)$ mice. GAPDH was used as an internal loading control (Fig. 2A). The results revealed that the expression of Miz1 was significantly higher in the cortex of AD mice compared with WT mice $(\mathrm{P}<0.05$; Fig. 2A). No significant difference was observed in Mizl expression in the hippocampus between the groups (Fig. 2B).

Elevated Mizl mRNA expression in the cortex of AD mice. RT-qPCR was used to analyze Miz1 mRNA fold changes in the groups ( $\mathrm{n}=3$; Fig. 3 ). The results indicated that Miz1 expression was significantly higher in the cortex of AD mice compared with WT mice (Fig. 3A; P<0.01). However, no significant difference was observed in the hippocampus between WT and AD mice (Fig. 3B).

Mizl expression in mouse brain tissue detected by immunofluorescence. The role of inflammation in the pathophysiology of AD is well-established $(21,22)$. Astrocytes are regarded as the most important inflammation cells (25). The location of Miz1 in the WT and AD mouse brain tissues was assessed via immunofluorescence assay. The results indicated that Mizl (green) was co-expressed with GFAP (red) in both the cortex and hippocampus of WT and AD mice (Fig. 4). It was also observed that Miz1 was co-expressed with MAP2 in the brains of WT and AD mice. Furthermore, Miz1 was predominantly found in the cytoplasm of neurons. These results indicate that the expression of Miz1 in astrocytes may be associated with inflammation in the pathology of $\mathrm{AD}(26-29)$. 
A

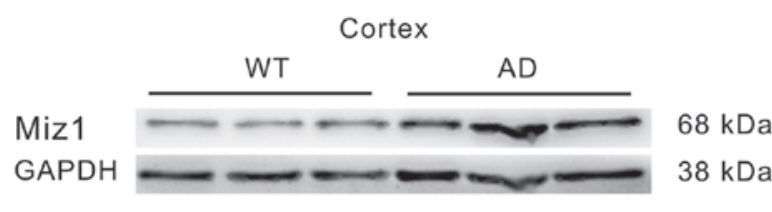

B

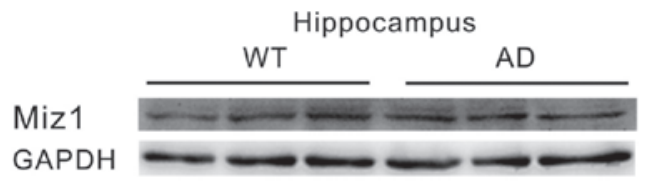

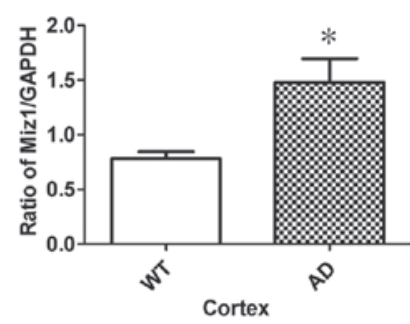

$68 \mathrm{kDa}$

$38 \mathrm{kDa}$

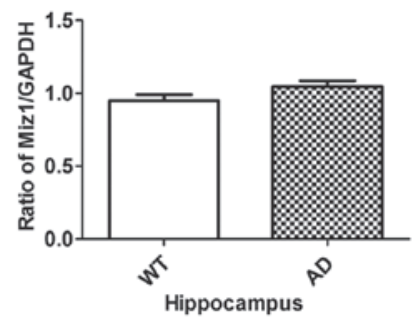

Figure 2. Western blot analysis of Miz1 expression in the cortex and hippocampus of WT and amyloid precursor protein/presenelin-1 AD model mice. Representative western blots and quantified data illustrating Miz1 expression in (A) the cortex and (B) the hippocampus of WT and AD mice relative to GAPDH, which was used as the loading control. $n=6$. ${ }^{*} \mathrm{P}<0.05$ vs. WT. Miz1, Myc-interacting zinc-finger protein 1; WT, wild-type; AD, Alzheimer's disease.
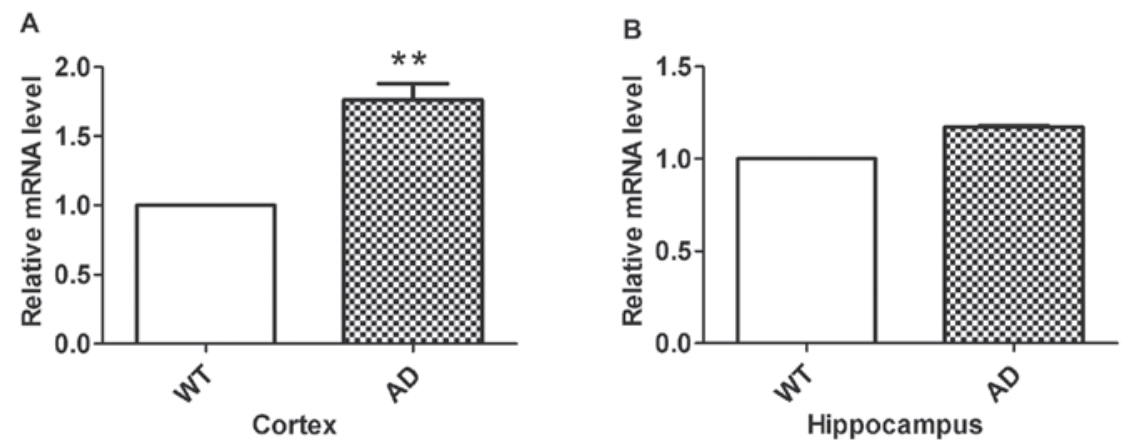

Figure 3. Reverse transcription-quantitative polymerase chain reaction was performed to assess Miz1 mRNA expression in (A) the cortex and (B) the hippocampus of WT and amyloid precursor protein/presenelin-1 AD model mice. The values are expressed as a fold-change using $\beta$-actin as a reference. $\mathrm{n}=3$. ${ }^{* *} \mathrm{P}<0.01$. Miz1, Myc-interacting zinc-finger protein 1; WT, wild-type; AD, Alzheimer's disease.

A

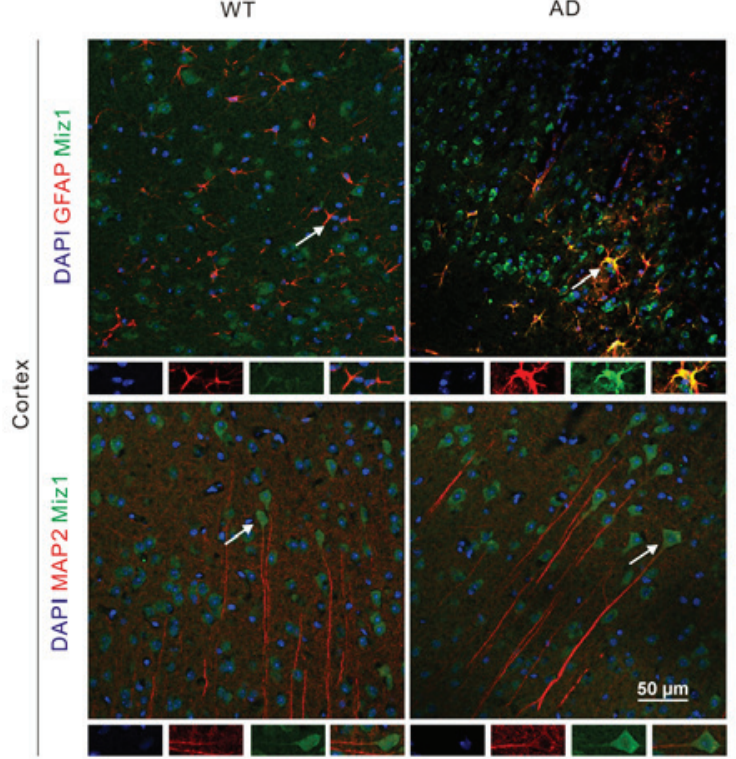

B

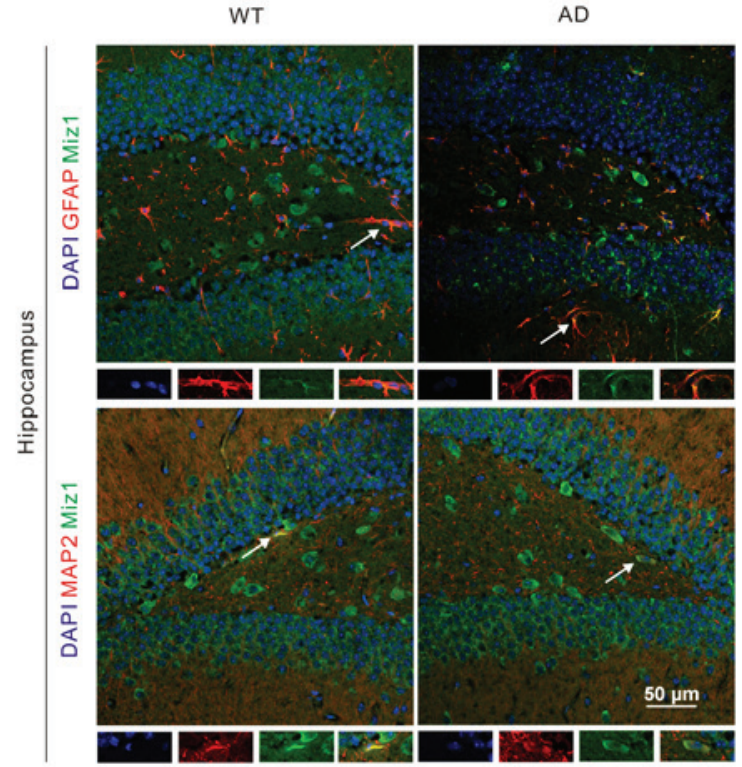

Figure 4. Immunofluorescence staining to assess the localization of Miz1. Miz1 (green) and GFAP/MAP2 (red) are co-expressed (merged, yellow) in the (A) cortex and (B) hippocampus of WT and amyloid precursor protein/presenelin-1 AD model mice. Arrows indicate cells positive for Miz1 and GFAP or MAP2. Magnification, x400. Miz1, Myc-interacting zinc-finger protein 1; GFAP, glial fibrillary acidic protein; MAP2, microtubule-associated protein 2; WT, wild-type; AD, Alzheimer's disease. 


\section{Discussion}

$\mathrm{AD}$ is an age-related neurodegenerative disorder characterized by accumulation of $\mathrm{A} \beta$ plaques, neurofibrillary tangles (NFTs), synaptic and neuronal loss, and cognitive decline (30). However, the underlying physiological mechanisms remain to be elucidated. It has been postulated that $\mathrm{A} \beta$ deposition and neurofibrillary tangles are critical factors in the pathogenesis of AD (31). Unfortunately, animal studies and clinical trials over the past 20 years have failed to manipulate levels of $A \beta$ and NFTs as targets for AD treatment (32-34). Therefore, there is a need to identify novel treatment targets and mediators associated with AD.

Miz1 serves a critical role in regulating proliferation, differentiation, cell cycle progression, and apoptosis (35-37). It also mediates DNA damage responses, lymphoid development and inflammation via transcriptional activation and repression of target genes (29). However, the cell cycle-independent functions of Miz1 are poorly understood (10). Previous observations have indicated that Miz1 has a broad expression profile, and it has also been detected in neural precursor cells and in different parts of the adult brain, indicating that the functions of Mizl extend beyond regulation of cell proliferation $(38,39)$. In the present study, it was demonstrated that Miz1 was broadly expressed in the cortex and hippocampus. Furthermore, Miz1 was detected in both neurons and astrocytes, suggesting that it may serve an important regulatory role in a wide variety of processes, including neuronal plasticity, neurotransmission and neuroinflammation. In the present study, it was observed that Miz1 levels were significantly increased in the cortex of $\mathrm{AD}$ mice. Consistent with this finding, $\mathrm{qPCR}$ analysis revealed that the mRNA levels of Miz1 were also increased in the cortex of AD mice. It is interesting to note that no significant differences were observed in Mizl expression in the hippocampus. Such region-specific alterations in Miz1 in AD mice may reflect region-specific signaling events associated, at least in part, with basal differences in distinct brain structures $(40,41)$.

The expression changes of Mizl in AD mice suggest that Miz1 may participate in the progression of AD. To the best of our knowledge, the present study is the first to indicate increased expression of Mizl in the cerebrum. However, the specific roles of Miz1 in AD remain unknown. Double-label immunofluorescence analysis revealed that Miz1 was co-expressed with Map-2 in neurons, indicating that Miz1 may be associated with neural plasticity. As a transcription factor, Mizl activates a variety of target genes in the brain. Multiple proteins encoded by target genes of Mizl are associated with synaptic surface receptor trafficking, synaptosome transport and endocytosis (10). Based on this, the increased Mizl expression in AD mice observed in the present study may be associated with synaptic dysfunction and thus impairments of cognition. However, Mizl was also observed in astrocytes, and it is known that astrocytes are the main effectors in the inflammatory process of the central nervous system (42). In lung tissue, Miz1 in the cytoplasm suppresses lipopolysaccharide- and tumor necrosis factor-induced inflammatory responses by specifically interfering with c-Jun $\mathrm{N}$-terminal kinase activation independently of its transcriptional activity, indicating that Mizl provides a critical transcriptional checkpoint preventing the host from excessive inflammatory response (26). However, whether Miz1 located in astrocytes in the central nervous system is associated with the anti-inflammatory process in AD remains unclear. Notably, the disruption of normal posttranslational modification-based signaling at the synapse is a pathological mechanism that likely contributes to cognitive dysfunction in diseases such as AD (43). A previous study reported that Miz1 may participate in small ubiquitin-like modifier (SUMO) conjugation and SUMO ligase activity (44). Therefore, Miz1 may also participate in AD progression through multiple mechanisms.

In summary, the results of the present study demonstrate that the expression of Miz1, which is a protein associated with a variety of functions including autophagy and inflammation, was altered in APP/PS1 mice. Subcellular localization suggests that Miz1 in neurons and astrocytes may serve a role in the pathology of AD. Since Miz1 promotes autophagy and inhibits inflammation and apoptosis, this suggests that the increased expression of Miz1 in APP/PS1 mice may be a compensatory response. However, the exact function of Mizl in AD requires further study to be fully understood.

\section{Acknowledgements}

The present study was supported by the National Natural Science Foundation of China (grant nos. 81171197 and 81220108010).

\section{References}

1. Portelius E, Zetterberg H, Skillbäck T, Törnqvist U, Andreasson U, Trojanowski JQ, Weiner MW, Shaw LM, Mattsson N and Blennow K; Alzheimer's Disease Neuroimaging Initiative: Cerebrospinal fluid neurogranin: Relation to cognition and neurodegeneration in Alzheimer's disease. Brain 138: 3373-3385, 2015.

2. Ossenkoppele R, Pijnenburg YA, Perry DC, Cohn-Sheehy BI, Scheltens NM, Vogel JW, Kramer JH, van der Vlies AE, La Joie R, Rosen HJ, et al: The behavioural/dysexecutive variant of Alzheimer's disease: Clinical, neuroimaging and pathological features. Brain 138: 2732-2749, 2015.

3. Haas LT, Salazar SV, Kostylev MA, Um JW, Kaufman AC and Strittmatter SM: Metabotropic glutamate receptor 5 couples cellular prion protein to intracellular signalling in Alzheimer's disease. Brain 139: 526-546, 2016.

4. Hendrickx A, Pierrot N, Tasiaux B, Schakman O, Kienlen-Campard P, De Smet C and Octave JN: Epigenetic regulations of immediate early genes expression involved in memory formation by the amyloid precursor protein of Alzheimer disease. PLoS One 9: e99467, 2014.

5. Parr C, Mirzaei N, Christian M and Sastre M: Activation of the Wnt/ $\beta$-catenin pathway represses the transcription of the $\beta$-amyloid precursor protein cleaving enzyme (BACE1) via binding of T-cell factor-4 to BACE1 promoter. FASEB J 29: 623-635, 2015.

6. Lai YJ, Liu L, Hu XT, He L and Chen GJ: Estrogen Modulates ubc9 expression and synaptic redistribution in the brain of APP/PS1 mice and cortical neurons. J Mol Neurosci 61: 436-448, 2017.

7. Yang J, Liu AY, Tang B, Luo D, Lai YJ, Zhu BL, Wang XF, Yan Z and Chen GJ: Chronic nicotine differentially affects murine transcriptome profiling in isolated cortical interneurons and pyramidal neurons. BMC Genomics 18: 194, 2017.

8. Liu J, Zhao Y, Eilers M and Lin A: Miz1 is a signal- and pathway-specific modulator or regulator (SMOR) that suppresses TNF-alpha-induced JNK1 activation. Proc Natl Acad Sci USA 106: 18279-18284, 2009.

9. Yang Y, Do H, Tian X, Zhang C, Liu X, Dada LA, Sznajder JI and Liu J: E3 ubiquitin ligase Mule ubiquitinates Mizl and is required for TNFalpha-induced JNK activation. Proc Natl Acad Sci USA 107: 13444-13449, 2010. 
10. Wolf E, Gebhardt A, Kawauchi D, Walz S, von Eyss B, Wagner N, Renninger C, Krohne G, Asan E, Roussel MF and Eilers M: Miz1 is required to maintain autophagic flux. Nat Commun 4: 2535, 2013.

11. Peukert K, Staller P, Schneider A, Carmichael G, Hänel F and Eilers M: An alternative pathway for gene regulation by Myc. EMBO J 16: 5672-5686, 1997.

12. Lu J, Chen M, Ren XR, Wang J, Lyerly HK, Barak L and Chen W: Regulation of hedgehog signaling by Myc-interacting zinc finger protein 1, Miz1. PLoS One 8: e63353, 2013.

13. Wu L, Wu H, Ma L, Sangiorgi F, Wu N, Bell JR, Lyons GE and Maxson R: Miz1, a novel zinc finger transcription factor that interacts with Msx2 and enhances its affinity for DNA. Mech Dev 65: 3-17, 1997.

14. Adhikary S, Peukert K, Karsunky H, Beuger V, Lutz W, Elsässer HP, Möröy T and Eilers M: Miz1 is required for early embryonic development during gastrulation. Mol Cell Biol 23: 7648-7657, 2003

15. Herold S, Hock A, Herkert B, Berns K, Mullenders J, Beijersbergen R, Bernards R and Eilers M: Miz1 and HectH9 regulate the stability of the checkpoint protein, TopBP1. EMBO J 27: 2851-2861, 2008 .

16. Saito M, Novak U, Piovan E, Basso K, Sumazin P, Schneider C, Crespo M, Shen Q, Bhagat G, Califano A, et al: BCL6 suppression of BCL2 via Miz1 and its disruption in diffuse large B cell lymphoma. Proc Natl Acad Sci USA 106: 11294-11299, 2009.

17. Campaner S, Doni M, Verrecchia A, Fagà G, Bianchi L and Amati B: Myc, Cdk2 and cellular senescence: Old players, new game. Cell Cycle 9: 3655-3661, 2010.

18. Herkert B, Dwertmann A, Herold S, Abed M, Naud JF, Finkernagel F, Harms GS, Orian A, Wanzel M and Eilers M: The Arf tumor suppressor protein inhibits Mizl to suppress cell adhesion and induce apoptosis. J Cell Biol 188: 905-918, 2010.

19. Kosan C, Saba I, Godmann M, Herold S, Herkert B, Eilers M and Möröy T: Transcription factor miz-1 is required to regulate interleukin-7 receptor signaling at early commitment stages of B cell differentiation. Immunity 33: 917-928, 2010.

20. He XL, Yan N, Chen XS, Qi YW, Yan Y and Cai Z: Hydrogen sulfide down-regulates BACE1 and PS1 via activating PI3K/Akt pathway in the brain of APP/PS1 transgenic mouse. Pharmaco Rep 68: 975-982, 2016.

21. Wang X, Liu P, Zhu H, Xu Y, Ma C, Dai X, Huang L, Liu Y, Zhang L and Qin C: miR-34a, a microRNA up-regulated in a double transgenic mouse model of Alzheimer's disease, inhibits bcl2 translation. Brain Res Bull 80: 268-273, 2009.

22. Wang J, Li N, Ma J, Gu Z, Yu L, Fu X, Liu X and Wang J: Effects of an amyloid-beta 1-42 oligomers antibody screened from a phage display library in APP/PS1 transgenic mice. Brain Res 1635: 169-179, 2016.

23. Murdock DG, Bradford Y, Schnetz-Boutaud N, Mayo P, Allen MJ D'Aoust LN, Liang X, Mitchell SL, Zuchner S, Small GW, et al: KIAA1462, a coronary artery disease associated gene, is a candidate gene for late onset Alzheimer disease in APOE carriers. PLoS One 8: e82194, 2013.

24. Livak KJ and Schmittgen TD: Analysis of relative gene expression data using real-time quantitative PCR and the 2(-Delta Delta C(T)) Method. Methods 25: 402-408, 2001

25. Nam Y, Kim JH, Seo M, Kim JH, Jin M, Jeon S, Seo JW, Lee WH, Bing SJ, Jee Y, et al: Lipocalin-2 protein deficiency ameliorates experimental autoimmune encephalomyelitis: The pathogenic role of lipocalin-2 in the central nervous system and peripheral lymphoid tissues. J Biol Chem 289: 16773-16789, 2014.

26. Do-Umehara HC, Chen C, Urich D, Zhou L, Qiu J, Jang S, Zander A, Baker MA, Eilers M, Sporn PH, et al: Suppression of inflammation and acute lung injury by Miz1 via repression of C/EBP- $\delta$. Nat Immunol 14: 461-469, 2013.
27. Heneka MT, Carson MJ, El Khoury J, Landreth GE, Brosseron F, Feinstein DL, Jacobs AH, Wyss-Coray T, Vitorica J, Ransohoff RM, et al: Neuroinflammation in Alzheimer's disease. Lancet Neurol 14: 388-405, 2015.

28. Heppner FL, Ransohoff RM and Becher B: Immune attack: The role of inflammation in Alzheimer disease. Nat Rev Neurosci 16: 358-372, 2015.

29. Chen P, Wang W, Zhang Y, Yuan Y and Wu Y: Decreased MIZ1 expression in severe experimental acute pancreatitis: A rat study. Dig Dis Sci 61: 758-766, 2016.

30. Gjoneska E, Pfenning AR, Mathys H, Quon G, Kundaje A, Tsai LH and Kellis M: Conserved epigenomic signals in mice and humans reveal immune basis of Alzheimer's disease. Nature 518: 365-369, 2015.

31. Reddy PH, Manczak M, Yin X, Grady MC, Mitchell A, Kandimalla R and Kuruva CS: Protective effects of a natural product, curcumin, against amyloid $\beta$ induced mitochondrial and synaptic toxicities in Alzheimer's disease. J Investig Med 64: 1220-1234, 2016

32. Giacobini E and Gold G: Alzheimer disease therapy-moving from amyloid- $\beta$ to tau. Nat Rev Neurol 9: 677-686, 2013.

33. Herrup K, Carrillo MC, Schenk D, Cacace A, Desanti S, Fremeau R, Bhat R, Glicksman M, May P, Swerdlow R, et al: Beyond amyloid: Getting real about nonamyloid targets in Alzheimer's disease. Alzheimers Dement 9: 452-458.e1, 2013.

34. Vandenberghe R, Rinne JO, Boada M, Katayama S, Scheltens P, Vellas B, Tuchman M, Gass A, Fiebach JB, Hill D, et al: Bapineuzumab for mild to moderate Alzheimer's disease in two global, randomized, phase 3 trials. Alzheimers Res Ther 8: 18, 2016.

35. Si J, Yu X, Zhang Y and DeWille JW: Myc interacts with Max and Mizl to repress C/EBPdelta promoter activity and gene expression. Mol Cancer 9: 92, 2010.

36. Kerosuo L and Bronner ME: Biphasic influence of Miz1 on neural crest development by regulating cell survival and apical adhesion complex formation in the developing neural tube. Mol Biol Cell 25: 347-355, 2014.

37. Haikala HM, Klefstrom J, Eilers M and Wiese KE: MYC-induced apoptosis in mammary epithelial cells is associated with repression of lineage-specific gene signatures. Cell Cycle 15: 316-323, 2016.

38. Lein ES, Hawrylycz MJ, Ao N, Ayres M, Bensinger A, Bernard A, Boe AF, Boguski MS, Brockway KS, Byrnes EJ, et al: Genome-wide atlas of gene expression in the adult mouse brain. Nature 445: 168-176, 2007.

39. Sanz-Moreno A, Fuhrmann D, Zankel A, Reingruber H, Kern L, Meijer D, Niemann A and Elsässer HP: Late onset neuropathy with spontaneous clinical remission in mice lacking the POZ domain of the transcription factor Myc-interacting zinc finger protein 1 (Mizl) in Schwann cells. J Biol Chem 290: 727-743, 2015.

40. Schneider JS, Mettil W and Anderson DW: Differential effect of postnatal lead exposure on gene expression in the hippocampus and frontal cortex. J Mol Neurosci 47: 76-88, 2012.

41. Abdul-Rahman O, Sasvari-Szekely M, Ver A, Rosta K, Szasz BK, Kereszturi E and Keszler G: Altered gene expression profiles in the hippocampus and prefrontal cortex of type 2 diabetic rats. BMC Genomics 13: 81, 2012.

42. Xu L, He D and Bai Y: Microglia-mediated inflammation and neurodegenerative disease. Mol Neurobiol 53: 6709-6715, 2016.

43. Lee L, Dale E, Staniszewski A, Zhang H, Saeed F, Sakurai M, $\mathrm{Fa}^{\prime} \mathrm{M}$, Orozco I, Michelassi F, Akpan N, et al: Corrigendum: Regulation of synaptic plasticity and cognition by SUMO in normal physiology and Alzheimer's disease. Sci Rep 5: 11782, 2015.

44. Cheong MS, Park HC, Hong MJ, Lee J, Choi W, Jin JB, Bohnert HJ, Lee SY, Bressan RA and Yun DJ: Specific domain structures control abscisic acid-, salicylic acid-, and stress-mediated SIZ1 phenotypes. Plant physiol 151: 1930-1942, 2009. 